\title{
PERILAKU KONSUMSI PENGGUNA HP ANDROID SAMSUNG DI TOKO NEW ASLISEL KUALA SIMPANG MENURUT PERSPEKTIF EKONOMI ISLAM
}

\author{
Dwi Nona Oktaviani' ${ }^{1}$, Abdul Hamid², Nurjanah ${ }^{3}$
}

\begin{abstract}
ABSTRAK
Konsumsi dalam Islam bukan hanya kepuasan di dunia tapi juga kesejahteraan akhirat mencukupi kebutuhan dan bukan memenuhi kepuasan/ keinginan adalah tujuan aktivitas ekonomi Islam hal ini sebagaimana yang juga di alami para pelanggan yang membeli Hp Android di Toko New Aslisel dengan merek samsung. Para konsumen tersebut menggunakan Hp untuk kepentingan menunjang aktivitas kehidupan dan bukan hanya untuk meningkatkan status sosial saja, tentu hal ini tidak terlepas dari perilaku konsumsi masyarakat, berdasarkan permasalahan tersebut maka yang menjadi permasalahan dalam penelitian skripsi ini adalah bagaimana perilaku konsumsi pengguna HP Android Samsung di Toko New Aslisel Kualasimpang menurut perspektif ekonomi Islam dan bagaimana faktor yang mempengaruhi perilaku konsumsi pengguna HP Android Samsung di Toko New Aslisel Kualasimpang. Penelitian dalam skripsi ini termasuk dalam jenis penelitian lapangan dan kepustakaan dengan pendekatan kualitatif dengan teknik pengumpulan data berupa wawancara dan observasi yang dilakukan terhadap 8 orang responden. Analisis data dalam penelitian ini ialah dengan cara mereduksi data, menyajikan data serta menarik kesimpulan. Hasil dari penelitian ini menunjukkan bahwa tujuan material perilaku konsumsi dari para pembeli di Toko New Aslisel Kuala Simpang ialah untuk mempermudah dan meningkatkan komunikasi dalam keseharian dan membantu untuk menyelesaikan pekerjaan sehari-hari terkait dengan profesi yang mereka tekuni sedangkan tujuan spiritual ialah untuk menambah pengetahuan keagamaan melalui aplikasi video di youtube serta dapat memasang aplikasi pengingat waktu sholat. Faktor internal yang mempengaruhi pembelian HP Android Samsung ialah karena kebutuhan profesi atau pekerjaan sedangkan faktor eksternal yang mempengaruhi ialah karena faktor kualitas HP Samsung yang tahan lama dan memiliki ram yang besar serta faktor lingkungan.
\end{abstract}

Kata Kunci: Perilaku Konsumsi, Handphone Android, Perspektif Ekonomi Islam

\footnotetext{
${ }^{1}$ Fakultas Ekonomi dan Bisnis Islam IAIN Langsa/ dwinonaokaviani@gmail.com

${ }^{2}$ Fakultas Ekonomi dan Bisnis Islam IAIN Langsa/ hamidzckl@gmail.com

${ }^{3}$ Fakultas Ekonomi dan Bisnis Islam IAIN Langsa/ nurjannah@iainlangsa.ac.id
} 


\section{ABSTRACT}

The purpose of consumption in Islam is not only satisfaction in the world but also the welfare of the hereafter to fulfill needs and not fulfill satisfaction / desires is the goal of Islamic economic activity this is what is also experienced by customers who buy Android phones at New Aslisel Stores with Samsung brands. These consumers use cell phones for the benefit of life activities and not just to improve social status, of course this is inseparable from people's consumption behavior, based on these problems, the researcher wants to examine in this thesis about "Consuming Behavior of Samsung Android Cellphone Users in New Stores Aslisel Kualasimpang According to Islamic Economic Perspective ". The problem in this thesis research is How is the consumption behavior of Samsung Android cellphone users in Kualanimpang New Aslisel Store from an Islamic economic perspective? What are the factors that influence the consumption behavior of Samsung Android HP users in Kualasimpang New Aslisel Store ?. The research in this thesis is included in the type of field research and literature with a qualitative approach with data collection techniques in the form of interviews and observations conducted on 8 respondents. Data analysis in this research is by reducing data, presenting data and drawing conclusions. The results of this study indicate that the material goals in the consumption behavior of buyers at the New Aslisel Kuala Simpang Shop are to facilitate and improve daily communication and help to complete daily work related to the profession they pursue while the spiritual goal is to increase knowledge religious through a video application on YouTube and can install prayer time reminder applications.

Keywords: Consumption Behavior, Angdroid Mobile, Islamic Economic Perspective

\section{PENDAHULUAN}

\section{Latar Belakang Masalah}

Perkembangan teknologi informasi yang semakin canggih dan mudah didapat menjadikan banyak sektor usaha yang memanfaatkannya sebagai sarana dalam transaksi menawarkan barang dan jasa. Hal ini dapat mendukung kegiatan kewirausahaan semakin berkembang dengan pesat. Kewirausahan adalah usaha untuk menciptakan nilai melalui pengenalan kesempatan bisnis, manajemen pengambilan risiko yang tepat, dan melalui keterampilan komunikasi untuk mobilisasi manusia, uang dan bahan-bahan baku sumber daya lain yang diperlukan untuk menghasilkan proyek dapat terlaksana dengan baik.(Morissa, 2010)

Salah satu perkembangan teknologi yang berpengaruh di masyarakat pada era global ini adalah android, Android yang dalam beberapa tahun terakhir ini melanda seluruh dunia, dan termasuk di Indonesia kini menjadi fenomena tersendiri. Pada awalnya android hanya ditujukan untuk kalangan atas. Tujuan dari kepemilikan android 
tersebut adalah untuk menunjang aktivitas sehari-hari kepada pengguna yang memiliki mobilitas tinggi dengan kebutuhan yang multi tasking Sehingga untuk memenuhi kebutuhan tersebut, diciptakan device a gadget yang mampu memenuhi hal tersebut yang kita kenal dengan android. Fenomena yang muncul sedikitnya ada dua hal. Memiliki android memang karena didasari kebutuhan dan beberapa di antaranya, pemilik android hanya untuk mempertahankan status sosial.(Indra, 2015)

Salah satu merek android yang banyak digunakan di kalangan masyarakat Indonesia ialah Samsung. Samsung telah melejit menjadi produsen android terbesar di dunia dengan angka pencapaian produk mencapai 86 juta unit pada kuartal ketiga 2017, Menurut wakil Presiden Samsung Mobile Business Andreas Rompis dalam acara peluncuran Samsung Galaxy S III Mini di Jakarta mengatakan bahwa pada pasar Android Indonesia, Samsung memiliki pangsa sebesar 80 persen. Dari 5 pengguna Android, 4 di antaranya memakai produk Samsung. Tingginya angka penggunaan android dengan merek samsung di Indonesia pada dasarmya tidak terlepas dari karakter manusia yang memiliki perilaku konsumtif sebagai makhluk ekonomi.

Pada hakikatnya manusia adalah homo economicus, kata ini berasal dari bahasa latin yang artinya manusia ekonomi. Homo economicus merupakan sosok manusia yang rasional dan berkebebasan dalam menentukan pilihan-pilihan yang ada untuk mencapai tujuan tertentu. Sehingga dalam setiap perilakunya manusia harus lebih bersifat rasional dalam memilih sumber daya yang ada. Perilaku konsumen didefinisikan sebagai studi tentang unit pembelian (buying units) dan pertukaran yang melibatkan perolehan, konsumsi dan pembuangan barang jasa, pengalaman serta ide-ide. Seorang muslim akan mencapai tingkat konsumsi yang baik atau mencapai utilitas (kepuasan) maksimal dalam kegiatan konsumsi apabila konsumsi yang dilakukan sesuai dengan ajaran agama. Kaidah yang dapat diacu sebagai pedoman dalam berkonsumsi adalah surah Al-Furgan ayat 67 :

Artinya: "Dan orang-orang yang apabila membelanjakan (harta), mereka ridak berlebihan, dan tidak (pula) kikir, dan adalah (pembelanjaan itu) di tengahtengah antara yang demikian." (Q.s. Al-Furqan: 67)

Dalam tafsir Jalalain menyebutkan bahwa sifat ibadurrahman sebagaimana yang disebutkan pada ayat di atas adalah ketika mereka berinfak pada keluarga mereka tidak berlebihan dan tidak pelit. Mereka membelanjakan harta mereka di tengah dengan sifat pertengahan (Jalalain, 2008). Ayat tersebut juga menjelaskan prilaku ckonomi muslim tidak hanya berorientasi pada kepuasan pribadi, tetapi lebih pada menjalankan peran sebagai khalifah di muka bumi yang diatur berdasarkan syariah dimana tujuan akhir dari ekonomi adalah terciptanya maslahah dalam meraih falah (Sumar'in, 2013)

Pada kenyataannya perilaku manusia khususnya perilaku konsumsi lebih mengarah pada perilaku konsumtif. Jika diperhatikan lebih lanjut, perilaku konsumtif ini cenderung terjadi di masyarakat dalam kehidupan sehari-hari sebagaimana hasil observasi awal yang peneliti temukan di lapangan terkait pengguna Hp Android dengan 
merek Samsung pada toko New Aslisel di Kuala Simpang Aceh Tamiang sebagai merek Android yang paling banyak di gunakan di Indonesia maka di toko New Aslisel di Kuala Simpang android dengan merek samsung juga yang paling banyak di cari oleh para pelanggan. Kebanyakan pelanggan yang membeli Hp Android dengan merek samsung tersebut masihlah terbilang usia remaja atau usia dewasa yang tujuan pembelian ialah untuk anaknya yang masih berada pada usia remaja juga Pelanggan yang membeli Hp android samsung tersebut menggunakan Hp bukan untuk kepentingan menunjang aktivitas kehidupan melainkan untuk meningkatkan status sosial saja, tentu hal ini tidak terlepas dari perilaku konsumsi masyarakat.

Tujuan konsumsi dalam Islam bukan hanya kepuasan di dunia tapi juga kesejahteraan akhirat mencukupi kebutuhan dan bukan memenuhi kepuasan/ keinginan adalah tujuan aktivitas ekonomi Islam. (Adiwarman, 2012) Terdapat prinsip dalam sistem ekonomi Islam dalam menyikapi permasalahan tentang perilaku konsumen, termasuk konsumsi di dalamnya yakni hidup hemat dan tidak bermewah-mewah Dari uraian diatas yang telah penulis paparkan, maka penulis tertarik untuk melakukan penelitian yang akan dibuat dalam bentuk skripsi dengan mengangkat judul "Perilaku Konsumsi Pengguna HP Android Samsung di Toko New Aslisel Kualasimpang Menurut Perspektif Ekonomi Islam"

\section{Rumusan Masalah}

1. Bagaimana perilaku konsumsi pengguna HP Android Samsung di Toko New Aslisel Kualasimpang menurut perspektif ekonomi Islam?

2. Bagaimana faktor yang mempengaruhi perilaku konsumsi pengguna HP Android Samsung di Toko New Aslisel Kualasimpang?

\section{Landasan Teorites}

\section{a. Pengertian Perilaku Konsumsi}

Perilaku konsumsi yang dikenal dalam bahasa Inggris consumtion behavior makin penting keberadaannya sctelah ekonom Inggris John Mynar Lord Kynes memperkenalkan teorinya yang dikenal dengan istilah Low of Consumtion (hukum konsumsi) yang belakangan mengilhami para penulis ilmu ekonomi mempopulerkan istilah perilaku konsumen dalam tulisan mereka.

Menurut Engel, perilaku konsumsi adalah tindakan yang langsung dalam mendapatkan, mengkonsumsi dan menghabiskan produk dan jasa, termasuk proses keputusan yang mendahului dan mengikuti tindakan itu. Sedangkan menurut London dan Bitta, perilaku konsumsi adalah suatu proses pengambilan keputusan yang mensyaratkan perilaku individu untuk mengevaluasi, memperoleh, menggunakan dan mengatur barang dan jasa. Adapun menurut Kotler dan Amstrong, perilaku konsumsi adalah perilaku individu atau pun rumah tangga dalam bentuk pembelian barang dan jasa untuk konsumsi personal (Nasri, 2013). 
Dari beberapa pengertian tersebut dapat dirangkup beberapa komponenkomponen seperti berikut:

1. Perilaku konsumsi menyoroti perilaku individu dan rumah tangga,

2. Perilaku konsumsi menyangkut suatu proses keputusan sebelum pembelian serta tindakan dalam memperoleh, memakai dan menghabiskan produk; dan

3. Perilaku konsumsi meliputi perilaku yang dapat diamati seperti jumlah yang dibeli, kapan, dengan siapa dan oleh siapa serta bagaimana barang yang sudah dikonsumsi.

Islam sebagai pedoman hidup tidak menonjolkan standar atau sifat kepuasan dari sebuah perilaku konsumsi sebagaimana yang dianut dalam ilmu ekonomi konvensional seperti utilitas dan kepuasan marginal, melainkan lebih menonjolkan aspek normatif Kepuasan dari sebuah aspek konsumsi menurut Islam harus berlandaskan pada tuntutan ajaran Islam itu sendiri. Dalam hal ini Muhammad Nejatullah Siddiqi mengatakan, konsumen harus puas akan perilaku konsumsinya dengan mengikuti norma-norma dalam Islam. Konsumen muslim seharusnya tidak mengikuti gaya konsumsi kaum xanthous (orang-orang berkulit kuning dan berambut kecoklat-coklatan) yang berkarakteristik menurut hawa nafsu. ${ }^{4}$

Pada dasarnya perilaku konsumsi seseorang atau sebuah rumah tangga, menurut Salvote adalah selalu berpijak atau berorientasi pada prinsip atau nilai kepuasan. ${ }^{5}$ Utilitas dan kepuasan marginal dapat merubah kepuasan yang dihasilkan dengan mengkonsumsi lebih banyak atau lebih sedikit komoditi. Semakin tingi tingkat pendapatan, semakin tingg pula tingkat konsumsi yang akan dicapai dalam perilaku konsumsi. Walau demikian kepuasan marginal atau kepuasan ekstra, baik dalam arti lebih maupun dalam arti kurang. Kemudian dalam mencapai kepuasan maksimal, tindakan pembelanjaan harus ditopang dengan aneka komoditi atau barang dan jasa konsumsi secara seimbang.

\section{b. Tujuan Perilaku Konsumsi}

Kegiatan ekonomi yang pada dasarnya lebih bersifat suatu ikhtiar untuk memenuhi kebutuhan hidup bersama seluruh individu, namun dalam perjalanannya berubah menjadi suatu upaya yang memperbesar kepemilikan atau persediaan, karena itu yang menonjol kemudian adalah keserakahan dalam memiliki persediaan material dan bukan lagi sarana untuk dapat mencukupkan persediaan akan kebutuhan yang ada. Hal ini menurut Muchasin (2003), secara makro terlihat jelas dalam pengerukan sumber daya alam secara besar-besaran di satu sisi dan hasil dari pengerukan itu dikonsumsi dengan cara yang sangat tidak hemat di lain sisi.

Machasin menambahkan, perilaku konsumsi seseorang tidak hanya bersifat atau bertujuan memenuhi kebutuhan hidupnya semata, tetapi juga untuk memenuhi tuntutan

\footnotetext{
${ }^{4}$ Muhammad Nejatullah Siddiqi, The Ekonomic Enterprise, diterjemahkan oleh Anas sidik, Kegiatan Ekonomi Dalam Islam (Cet. Ke-2, Jakarta: Bumi Aksara, 2006), hal. 96

${ }^{5}$ Rudy Sitompul, Teori Mikro Ekonomi (Cet Ke-3, Jakarta. Erlangga, 2005), hal. 67 
perilaku konsumsi dan penilaian orang-orang lain demi sebuah kepercayaan diri dan martabat kemanusian. Machasin mencontohkan, orang yang hanya memiliki sepeda merasa lebih rendah dari pada orang yang memiliki sepeda motor, orang yang naik sepeda motor merasa minder di hadapan orang yang naik mobil. Demikian seterusnya sehingga dapat dikatakan semakin banyak, mahal dan canggih produk-produk material yang dimiliki seseorang, semakin tinggi martabatnya dan semakin tinggi kepercayaan dirinya.

Dalam pandangan Islam, perilaku konsumsi mempunyai tujuan yang tidak Seperti tujuan perilaku konsumsi menurut ilmu ekonomi konvensional yang hanya sepe ingin memenuhi kebutuhan jasmaniah lahiriah, melainkan ingin di samping memenuhi kebutuhan jasmaniah lahiriah, juga memenuhi kebutuhan rohaniah batiniah.

\section{c. Etika Konsumsi Dalam Islam}

\section{1) Mensyukuri Nikmat Allah}

Mensyukuri ekonomi dan harta kekayaan (al-Mal) itu antara lain dengarn jalan yang serba halalan thayyiban, baik dalam hal produksi dan distribusinya, maupun terutama dalam memperoleh dan mengonsumsinya. Mengkonsumsi barang dan jasa yang halal merupakan syarat utama bagi kehidupan manusia Muslim yang menghendaki kehidupan yang baik

\section{2) Gemar Bersedekah}

Selain dikenai kewajiban zakat, setiap Muslim juga dianjurkan untuk berinfak dan bersedekah. Banyak ayat yang melukiskan keistimewaan sedekah, diantaranya Q.S. al-Baqarah/2: 261-262.

\section{3) Larangan Pelit}

Pelit, kikir, atau bakhil adalah salah satu sifat yang dibenci al-Qur'an dan Hadits, diantaranya dalam Q.S. al-Hadiid/57:23-24

Artinya:"(Kami jelaskan yang demikian itu) supaya kamu jangan berduka cita terhadap apa yang luput dari kamu, dan supaya kamu jangan terlalu gembira terhadap apa yang diberikan-Nya kepadamu. Dan Allah tidak menyukai setiap orang yang sombong lagi membanggakan diri, (yaitu) orang-orang yang kikir dan menyuruh manusia berbuat kikir. Dan barangsiapa yang berpaling (dari perintah-perintah Allah) maka sesungguhnya Allah Dia-lah Yang Maha Kaya lagi Maha Terpuji." (QS Al-Hadid: 23-24).

Dalam tafsir Ibnu Katsir dijelaskan bahwa maksud ayat diatas ialah bahwa Allah swt memberitahukan kepada manusia tentang Ilmu dan ketetapan Allah atas segala sesuatu sebelum kejadiannya dan ukuran-ukuran yang dibuat untuk semua makhluk sebelum keberadaannya maka dari itu janganlah manusia berbangga diri terhadap nikmat yang telah diberikan oleh Allah karena sesungguhnya nikmat tersebut bukanlah dari usaha dan hasil jerih payah manusia semata melainkan semata-mata karena takdir Allah dan pemberian rezeki-Nya kepada setiap manusia. 
Maka janganlah nikmat tersebut menjadikan seseorang angkuh, sombong dan kikir terhadap manusia lainnya.(Ibnu Katsir, )

\section{4) Larangan Boros}

Larangan boros ini terdapat dalam Q.S. al-Isra/17: 26-27

Artinya "Dan berikanlah kepada keluarga-keluarga yang dekat akan haknya, kepada orang miskin dan orang yang dalam perjalanan; dan janganlah kamu menghambur-hamburkan (hartamu) secara boros. Sesungguhnya pemborospemboros itu adalah saudara-saudara syaitan dan syaitan itu adalah sangat ingkar kepada.(Q.S. Al-Isra 26-27).

Dalam tafsir Ibnu Katsir ( terkait ayat diatas seseungguhnya Allah swt memberi perintah untuk memberi nafkah kepada orang yang mebutuhkan lalu kemudian Allah swt melarang sikap berlebih-lebihan dalam membelanjakan harta tetapi yang dianjurkan ialah yang pertengahan sebab tindakan yang berlebihan merupakan perbuatan setan.

\section{METODE PENELITIAN}

\section{Pendekatan dan Jenis Penelitian}

Jenis penelitian yang akan digunakan dalam penelitian ini adalah jenis penelitian field research yaitu jenis penelitian lapangan yang dilakukan secara langsung dengan menjadikan penelitian menjadi sumber untuk mendapatkan data- data, informasi, dan laporan yang sesuai dengan keperluan yang akan dibahas dalam penulisan ini.

Pendekatan yang akan digunakan dalam penelitian ini adalah pendekatan kualitatif. Metode kualitatif merupakan metode penelitian yang ditujukan untuk memahami fenomena-fenomena sosial dari sudut pandang partisipan. Dengan demikian dapat dipahami bahwa penelitian kualitatif adalah penelitian yang digunakan untuk meneliti pada kondisi objek alamiah dimana peneliti merupakan instrumen kunci.

\section{Lokasi dan Waktu Penelitian}

Penelitian ini dilaksanakan di Toko New Aslisel Kuala Simpang Kabupaten Aceh Tamiang dari bulan Mai sampai Juli 2019. Alasan peneliti mengambil lokasi tersebut sebagai tempat penelitian karena objek yang akan diteliti mengenai perilaku konsumi pengguna Hp Android Samsung berada di toko tersebut, dan mudah dijangkaunya tempat penelitian serta terdapat masalah yang akan diteliti.

\section{Informan Penelitian}

Informan dalam penelitian ini adalah 8 orang pembeli HP Android Samsung di toko New Asli Sel Kota Kuala Simpang. Pembeli yang akan ditetapkan dalam penelitian ini sebagai informan penelitian ialah sebanyak 8 orang pembeli yang datang ke toko New Asli Sel pada saat peneliti melakukan penelitian di Toko Tersebut. 


\section{Teknik Pengumpulan Data dan Analisis Data}

Teknik pengumpulan data merupakan langkah strategis dalam penelitian karena tujuan utama dari penelitian adalah mendapatkan data. Dalam penelitian ini teknik pengumpulan data yang digunakan antara lain wawancara, observasi dan dokumentasi.

Dalam penelitian kualitatif data diperoleh dari berbagai sumber dengan menggunakan teknik pengumpulan data yang bermacam-macam (triagulasi) yang dilakukan secara terus menerus sampai datanya jenuh. maka data harus dianalisis. Analisis data merupaka menyusun secara sistematis data yang diperoleh observasi serta dokumentasi dan bahan-bahan lainnya, sehingga dapat mudah dipahami dan temuannya dapat dinformasikan kepada orang lain.

Analisis dapat mudah isis data dalam penelitian kualitatif dilakukan pada saat pengumpulan data berlangsung serta selesai pengumpulan data dalam periode tertentu. Analisis data dilakukan dengan cara mereduksi data, menyajikan data serta menarik kesimpulan.

\section{HASIL DAN PEMBAHASAN}

\section{Perilaku Konsumsi Pengguna HP Android Samsung di Toko New Aslisel Kualasimpang Menurut Perspektif Ekonomi Islam}

Teori prilaku konsumen (consumer behavior) mempelajari bagaimana manusia memilih diantara berbagai pilihan yang dihadapinya dengan memanfaatkan sumber daya yang similikinya. Perilaku konsumsi dalam ekonomi Islam berdasarkan prinsip keadilan, prinsip kebersihan, prinsip kesederhanaan, kemurahan hati, dan moralitas. Konsumsi pada hakikatnya adalah mengeluarkan sesuatu dalam rangka memenuhi kebutuhan. Konsumsi meliputi keperluan, kesenangan dan kemewahan. Kesenangan atau keindahan diperbolehkan asal tidak berlebihan, yaitu tidak melampaui batas yang dibutuhkan oleh tubuh dan tidak pula melampaui batas-batas makanan yang dihalalkan.

Dalam penelitian skripsi ini peneliti membahas tentang perilaku konsumsi yang mencakup beberapa aspek yaitu tujuan perilaku konsumsi, prinsip konsumsi dalam Islam dan etika konsumsi dalam Islam. Pembahasan yang pertama ialah tentang aspek tujuan dalam perilaku konsumsi. Dalam pandangan Islam, perilaku konsumsi mempunyai tujuan yang tidak seperti tujuan perilaku konsumsi menurut ilmu ekonomi konvensional yang hanya ingin memenuhi kebutuhan jasmaniah lahiriah, melainkan memiliki dua tujuan yaitu tujuan material dan tujuan spiritual. Tujuan material dalam konsumsi Islam ialah untuk memberikan kehidupan yang baik dan nyaman menurut syara' sedangkan tujuan spiritual konsumsi dalam Islam ialah untuk dapat meningkatkan nilai-nilai Islam dalam kehidupan. Terkait pengguna $\mathrm{Hp}$ Android Samsung di Toko New Aslisel peneliti melakukan wawancara dengan para konsumen di Toko New Aslisel sebanyak 8 responden dengan hasil sebagai berikut:

"Saya menggunakan Hp samsung untuk keperluan kerja seperti menginput data ke laptop,jadi walaupun saya sedang diluar saya juga bisa mengerjakan pekerjaan 
saya. Saya sering menonton video ceramah melalui hp, jadi bisa menambah pengetahuan juga di bidang agama"

"Saya menggunakan hp samsung karena hp samsung untuk kebutuhan berkomunikasi, dan juga untuk mencari informasi, selain itu saya juga sering membagikan konten-konten ceramah ataupun kalimat-kalimat nasehat di media sosial saya"

"Saya membeli hp samsung untuk keperluan komunikasi dan juga keperluan kerja, banyak manfaat yang saya rasakan menggunakan hp samsung terlebih di zaman digital seperti ini, saya sering menggunakan hp untuk mengirim video ceramah dan juga konten-konten islami”

Berdasarkan hasil wawancara yang peneliti lakukan dengan ketiga responden diatas dapat diketahui bahwa tujuan material dalam membeli dan menggunakan HP Samsung Android ialah untuk memenuhi kebutuhan komunikasi dan kegiatan seharihari dalam mempermudah dan memperlancar pekerjaan sebagaimana juga pernyataan dari responden yang merupakan pembeli HP Samsung Android sebagai berikut:

"Saya membeli hp samsung untuk anak saya yang masi sekolah, dengan menggunakan hp saya jadi mudah untuk berkomunikasi dengan anak saya seperti menjemput anak dari sekolah atau pun les. Saya mengisi lagu-lagu islami di hp anak saya dan juga mendownload video- video cerita nabi dan sahabat".

"Saya membeli hp untuk samsung untuk anak, karena dia sekolah di sekolah kejuruan jadi dia mmbutuhkan hp untuk membantu tugas sekolahnya, anak saya juga mendownload aplikasi al-qur'an untuk dia mengaji”.

"Saya membeli hp samsung untuk hadiah anak saya,selain itu karena dia juga membutuhkan untuk alat komunikasi agar dia bisa menghubungi saya untuk di jemput ketika pulang sekolah. Sebagai orang tua saya sudah membuat pengaturan di hp agar saya bisa tau apa saja yang di download anak saya di hp tersebut, agar dia juga lebih memahami nilai-nilai islam saya juga sering mengirimkan videovideo ceramah di hp anak saya".

Berdasarkan hasil wawancara dengan ketiga responden diatas yang membeli HP Samsung untuk anak-anak mereka dapat diketahui bahwa tujuan material dalam perilaku konsumsi dari para pembeli tersebut ialah untuk mempermudah dan meningkatkan komunikasi dalam keseharian serta membantu untuk menyelesaikan pekerjaan sehari-hari tentang tugas sekolah anak-anak mereka. Selain itu responden berikut juga mnyatakan hal yang sama terkait pembelian HP Android Samsung di Toko New Aslisel sebagai berikut:

"Saya membeli hp samsung untuk keperluan jualan online, dengan hp samsung saya harap bisa memperlancar jualan online saya,dengan hp ini saya juga memasang aplikasi pengingat waktu sholat", 
"Saya membeli hp samsung untuk berjualan online, saya bisa mendapatkan uang engan hp yang saya punya, saya sering melihat video-video ceramah apa lagi yang berkenaan dengan jual beli online"

Berdasarkan wawancara dengan responden tersebut tujuan material dari pembelian dan penggunaan HP Samsung ialah untuk mempermudah komunikasi dan meningkatkan penjualan online untuk memenuhi kebutuhan hidup sehari-hari.

Hasil wawancara dengan para responden diatas menunjukkan bahwa tujuan material dari perilaku konsumsi dalam pembelian dan penggunaan HP Samsung merek Android adalah untuk mempermudah dan memperlancar komunikasi dalam keseharian da untuk membantu dan mempermudah menyelesaikan hal-hal yang berhubungan dengan pekerjaan sehari-hari. Sedangkan tujuan spiritual dalam perilaku konsumsi para pembeli ialah untuk dapat menambah wawasan pengetahuan keagamaan melalui aplikasi video di youtube serta dapat memasang aplikasi pengingat waktu sholat.

Selanjutnya aspek yang juga akan peneliti kaji dalam penelitian ini terkait perilaku konsumsi Islami selain aspek tujuan material dan spiritual yaitu aspek prinsip dalam konsumsi Islam. Ada dua prinsip utama yang harus diterapkan dalam perilaku konsumsi Islam yaitu prinsip kesederhanaan dan prinsip moralitas. Dalam prinsip kesederhanaan Islam menghendaki suatu kuantitas dan kualitas konsumsi yang wajar bagi kebutuhan manusia sehingga tercipta pola konsumsi yang efesien dan efektif secara individual maupun sosial sedangkan dalam prinsip moralitas maka kegiatan konsumsi bukan hanya mengenai penggunaan saja tetapi juga dengan tujuan akhirnya, yakni untuk peningkatan atau kemajuan nilai-nilai moral dan spritual sesuai ajaran Islam.

Berdasarkan hasil wawancara dengan para responden dapat diketahui bahwa prinsip kesederhanaan yang digunakan oleh para pembeli dalam memakai HP Android Samsung ialah dikarenakan HP tersebut memiliki daya tahan lama dan memori ram yang besar dibanding merek HP lainnya sehingga para pembeli tidak harus ganti HP dalam jangka waktu dekat dan lebih menghemat pengeluaran, selain itu prinsip moralitas yang di terapkan oleh pembeli dalam pembelian dan penggunaan HP Android Samsung ialah untuk dapat membantu dan menunjang aktivitas keseharian baik dalam bekerja, sekolah maupun berusaha dalam bisnis dan hal ini sesuai dengan prinsipprinsip Islam yang memerintahkan setiap muslim untuk bekerja dengan jalan yang baik dan halal.

Aspek selanjutnya terkait perilaku konsumsi dalam Islam ialah etika konsumsi yang harus diterapkan para pembeli agar sesuai dengan nilai-nilai Islam. Dalam penelitian ini aspek etika dalam konsumsi Islam ialah senantiasa bersyukur atas setiap hal yang dimiliki dan tidak boleh setiap benda atau barang yang kita miliki menjadikan kita semakin jauh dari nilai-nilai Islam, akan tetapi sebaliknya setiap hal yang dimiliki dan digunakan termasuk HP maka harus menjadikan pemiliknya semakin dekat dengan nilai-nilai Islam. Etika Islami dalam perilaku konsumsi selanjutnya yang harus 
diterapkan sesuai dengan nilai-nilai islam ialah tidak bersikap boros dengan melakukan hal-hal yang mubazir dan dibenci Allah. Melainkan sebaliknya harus bersikap hemat.

Hasil wawancara dengan para responden menunjukkan bahwa etika Islami dalam perilaku konsumsi para pembeli Di Toko New Aslisel menunjukkan bahwa etika syukur dalam ketergantungan terhadap HP masihlah dalam batas Islami. Para pembeli merasa membutuhkan HP untuk kebutuhan dan aktivitas sehari-hari yang tidak keluar dari nilainilai Islam yaitu untuk bekerja, mencari tugas sekolah, ataupun untuk berjualan dalam rangkan mencari rezeki. Sedangkan etika konsumsi Islam terhadap larangan boros masih diaplikasikan dengan semua pembeli hal ini dikarenakan ada pembeli yang akan mengganti HP jika HP yang dimiliki sudah rusak dan masih juga terdapat pembeli yang akan mengganti HP saat ada keluaran terbaru dan sudah merasa bosan dengan HP yang lama, hal ini tidak mencerminka etika konsumsi yang sesuai dengan nilai-nilai Islami.

\section{Faktor Yang Mempengaruhi Perilaku Konsumsi Pengguna HP Android Samsung di Toko New Aslisel Kualasimpang}

Perilaku konsumen adalah tindakan-tindakan yang dilakukan oleh individu, kelompok, atau organisasi yang berhubungan dengan proses pengambilan keputusan dalam mendapatkan, menggunakan barangbarang atau jasa ekonomis yang dapat dipengaruhi lingkungan. Pada dasarnya perilaku konsumen merupakan perilaku yang berhubungan dengan usaha untuk mendapatkan produk guna memenuhi kebutuhannya. Sepanjang proses yang berawal dari timbulnya kebutuhan sampai pada keputusan beli, mengkonsumsi produk dan menyingkirkan produk bila sudah habis atau tidak digunakan lagi. Secara garis besar ada 2 faktor yang mempengaruhi seseorang dalam perilaku konsumsi yaitu faktor internal dan faktor eksternal. Faktor internal adalah faktor yang berasal dari dalam diri seseorang seperti umur dan tahap daur hidup pembeli, jabatan, keadaan ekonomi, gaya hidup, kepribadian, konsep diri pembeli yang bersangkutan sedangkan faktor eksternal ialah hal-hal yang mempengaruhi perilaku konsumsi seseorang yang berasal dari luar seperti faktor kebudayaan, lingkungan, dan kelas social.

Berdasarkan hasil wawancara yang peneliti lakukan dengan 8 orang responden berikut ini maka dapat diketahui bahwa faktor-faktor yang mempengaruhi pembelian HP Android merek Samsung di Toko New Aslisel Kota Kuala Simpang ialah sebagai berikut:

"Saya menggunakan HP Android Merek Samsung sebenernya pada dasarnya karena kebutuhan pekerjaan yang mengharuskan. Sekarang guru harus menguasai teknologi untuk bahan mengajar, input nilai, data dan lain-lain trus selain itu Karen merek Samsung tahan lama dan ramnya besar sehingga tidak harus selalu ganti-ganti HP."

"Saya menggunakan HP Android Samsung untuk kebutuhan kerja di kantor dan komunikasi dengan rekan-rekan kerja yang lain. Merek Samsung yang saya pilih 
karena saya lihat rata-rata teman di Kantor pakai merek ini jadi saya ikut-ikutan saja."

"Saya memakai HP Android untuk kebutuhan kerja dan mempermudah komunikasi. Merek Samsung saya pakai karena lingkungan kantor banyak yang pakai merek ini."

"Saya pakai HP Android untuk kebutuhan jualan online dan merk Samsung yang saya pakai karena kualitasnya tahan lama dan punya ram yang besar. Cocok untuk kebutuhan saya yang butuh sering kirim gambar."

"HP Android saya butuhkan untuk keperluan jualan online dan kenapa saya pakai merek Samsung karena kualitas yang tahan lama dan harga yang masih dapat dijangkan serta memori ramnya besar."

"HP Android Samsung ini saya belikan untuk anak saya yang masih SMA dengan tujuan untuk membantu dia mengerjakan tugas sekolah dan karena dari sejak pertama saya dan suami pakai merek Samsung makanya untuk anak saya belikan merek yang sama."

“Anak saya membutuhkan HP Android Samsung untuk kebutuhan sekolah dan untuk menghubungi saya saat antar jemput sekolah dan saya pilihkan merek Samsung karena melihat iklan di TV dan merek ini kualitasnya lebih tahan lama disbanding merek yang lain.”

"Saya membelikan HP Android Samsung untuk anak saya untuk kebutuhan sekolah dia untuk cari tugas dan antar jemput saat pulang sekolah. Merek Samsung saya pilih karena anak saya bilang teman-temannya banyak yang pakai Samsung dan dia juga ingin pakai merek ini."

Hasil wawancara dengan para responden diatas menunjukkan bahwa ada beberapa faktor yang mempengaruhi perilaku konsumen dalam membeli HP Android Samsung di Toko New Aslisel Kuala Simpang yaitu faktor internal dan faktor eksternal. Faktor internal adalah faktor yang berhubungan dengan pribadi dari pembeli itu sendiri dan dalam penelitian ini di dapati bahwa faktor internal yang mempengaruhi pembelian HP Android Samsung ialah karena kebutuhan profesi atau pekerjaan yakni untuk mempermudah akses dalam bekerja baik responden yang berprofesi sebagai guru, pegawai kantor, penjual online maupun untuk siswa sekolah dalam memenuhi kebutuhan untuk tugas sekolah mereka. Sedangkan faktor eksternal yang mempengaruhi dalam perilaku konsumsi oleh pembelian HP Android Samsung ialah karena faktor kualitas HP Samsung yang tahan lama disbanding HP lainnya dan memiliki ram yang besar serta faktor lingkungan yaitu lingkungan disekitar responden banyak yang memakai HP tersebut sehingga responden tertarik untuk juga menggunakan HP Android merek Samsung. 


\section{KESIMPULAN}

Berdasarkan hasil penelitian "Perilaku Konsumsi Pengguna HP Android Samsung di Toko New Aslisel Kualasimpang Menurut Perspektif Ekonomi Islam” dapat disimpulkan sebagai berikut:

a. Perilaku konsumsi yang mencakup beberapa aspek yaitu tujuan perilaku konsumsi, prinsip konsumsi dalam Islam dan etika konsumsi dalam Islam. Hasil penelitian yang dilakukan menunjukkan bahwa tujuan material dalam perilaku konsumsi dari para pembeli di Toko New Aslisel Kuala Simpang tersebut ialah untuk mempermudah dan meningkatkan komunikasi dalam keseharian serta membantu untuk menyelesaikan pekerjaan sehari-hari terkait dengan profesi yang mereka tekuni , sedangkan tujuan spiritual ialah untuk menambah pengetahuan keagamaan melalui aplikasi video di youtube serta dapat memasang aplikasi pengingat waktu sholat. Prinsip kesederhanaan yang digunakan oleh para pembeli dalam memakai HP Android Samsung ialah penggunaan HP yang hemat, prinsip moralitas ialah untuk dapat membantu dan menunjang aktivitas keseharian baik dalam bekerja, sekolah maupun berusaha dalam bisnis sesuai nilai-nilai Islam. Etika Islami dalam perilaku konsumsi para pembeli Di Toko New Aslisel menunjukkan bahwa etika syukur dalam ketergantungan terhadap HP masihlah dalam batas Islami.

b. Faktor internal yang mempengaruhi pembelian HP Android Samsung ialah karena kebutuhan profesi atau pekerjaan yakni untuk mempermudah akses dalam bekerja baik responden yang berprofesi sebagai guru, pegawai kantor, penjual online maupun untuk siswa sekolah dalam memenuhi kebutuhan. Sedangkan faktor eksternal yang mempengaruhi ialah karena faktor kualitas HP Samsung yang tahan lama dan memiliki ram yang besar serta faktor lingkungan.

\section{DAFTAR PUSTAKA}

Al-Mahaly, Imam Jalaluddin dan Imam Jalaluddin As-Suyuti, Tafsir Jalallain Berikut Asbab An-Nuzulnya, Jilid 1, Bandung : Sinar Baru, 2008

Anto, Hendrie, Pengantar Ekonomi Mikro Islam, Yogyakarta: Ekonosia, 2003

Case KE \& RC. Fair Prinsip-prinsp Ekonomi (Wibi Hardani \& Devri Barnadi, Ed) Jilid 1 Edisi 8, Jakarta: Erlangga, 2007

Edwin Nasution, Mustafa dkk, Pengenalan Eksklusif Ekonomi Islam, Jakarta: Kencana, 2006

Ginting, Sarmanta, Perilaku Konsumsi Dalam Perspektif Ekonomi Islam, Blog Pribadi Sarmanta Ginting, http:/Khazanah Ilmu Perilaku Konsumsi Dalam Perspektif Ekonomi Islam html diakses pada 16 Juli 2018

Karim, Adiwarman A Ekonomi Mikro Isiam, Jakarta : Raja Grafindo Persada, 2012 
Kompas.com 4 dari 5 Pengguna Android di Indonesia Pakai Samsung" https:/tekno kompas.com/read/2013/01/15/17463288/4 dari.5,pengguna. android di indonesia pakai.samsung diakses pada tanggal 2 Agustus 2018

Machasin, Islam Teologi Aplikatif Cet. ISleman-Yogyakarta: Pustaka Alief, 2003

Morissan, dkk, Teori Komunikasi Massa. Bogor: Ghalia Indonesia, 2010

Mowen, John C dan Michael Minor, Perilaku Konsumen, alih bahasa oleh Lina Salim, Jakarta Erlangga 2002

Muflih, Muhammad Perilaku Konsumen dalam Perspekuf Ilmu Ekonomi Islam, Jakarta Raja Grafindo Persada, 2006

Narbuko, Cholid dan Abu Achmadi, Metodologi Penelitian, Jakarta: Bumi Aksara, 2002

Nejatullah Siddiqi, Muhammad The Ekonomic Enterprise, diterjemahkan oleh Anas sidik, Kegiatan Ekonomi Dalam Islam, Cet. Ke-2, Jakarta: Bumi Aksara, 2006

Quthb, Sayyid, Tafsir fi Zilalil Qur'an Jilid, Jakarta: Lentera Hati, 2002

Rahmadani, Indra, Pengaruh Gaya Hidup Konsumen Muslim Terhadap Adopsi Smartphone Apple (Studi Pada Mahasiswa Fakultas Ekonomi Dan Bisnis Universitas Airlangga) dalam jurnal JESTT Vol, 2 No. 3 Maret 2015

Sugiyono, Metode Penelitian Kananf Kualtatif Dan R\&D, Bandung: Alfabeta, 2012

Sumar'in, Ekonomi Islam "Sebuah Pendekatan Ekonomi Mikro Perspektif Islam" Yogyakarta Graha limu, 2013

Umar, Husein, Riset Pemasaran dan Perilaku Konsumen, Jakarta: PT Gramedia Pustaka Utam, 2002

Wahyunto, Masyarakat Konsumsi Cet, ke-1, Yogyakarta Kreasi Wacana, 2004 